\title{
Upaya Meningkatkan Hasil Belajar Keterampilan Manipulatif Lengan pada Pembelajaran Model Pendidikan Gerak Berformat Permainan
}

\author{
Risma Jati Rahayu \\ ${ }^{1}$ Program Studi Pendidikan Guru Sekolah Dasar Pendidikan Jasmani, Universitas Pendidikan Indonesia
}

\begin{abstract}
Info Artikel
SejarahArtikel:

Diterima Desember 2018

Disetujui Maret 2019

Dipublikasikan Mei 2019

Keywords:

Model Kooperatif, Partisipasi Belajar, Teams Games Tournament

Abstrak

Penelitian ini dimotivasi oleh rendahnya keterampilan manipulatif siswa di sekolah dasar, yang menunjukkan kurangnya perhatian guru pada keterampilan tersebut. Penelitian ini diarahkan untuk meningkatkan keterampilan manipulatif lengan dengan menerapkan model pendidikan gerak berformat permainan. Metode yang digunakan dalam penelitian ini adalah penelitian tindakan kelas dengan instrumen GPAI (Games Perfomance Assesment Instrument) dan catatan lapangan. Partisipan penelitian ini adalah 34 siswa, terdiri dari (17 laki-laki dan 17 perempuan). Terdapat peningkatan 9,54\% dari hasil pre test hingga siklus 2 tindakan 2. Dengan demikian dapat disimpulkan bahwa pembelajaran model pendidikan gerak berformat permainan dapat meningkatkan keterampilan manipulatif lengan terhadap siswa kelas 4.
\end{abstract}

\begin{abstract}
This research was motivated by the fact that so many children in elementary schools having low manipulative skills, which can be related to teacher's low attention to these skills. This study was directed to improve arm manipulation skills by using a game format on movement education model, using a classroom action research. GPAI (Games Performance Assessment Instrument) and field notes were employed as the instrument. The samples of this study were 34 student, consist of (17 boys and 17 girls). There was 9,54\% improvement that can be detected from the results of the pre test to the end of the cycle. It can be concluded that the game format of movement education model can improve arm manipulation skills of 4 th grade students. The implication of this research is that movement education models should be actively occupied in the PE lesson in elementary schools.
\end{abstract}




\section{PENDAHULUAN}

Pendidikan jasmani adalah suatu proses pendidikan yang menggunakan aktivitas fisik sebagai alatnya, proses pendidikan yang dimaksud disini adalah membantu siswa meningkatkan atau mengembangkan kemampuankemampuan yang berhubungan dengan kemampuan fisik, mental, emosional dan sosial. Pendidikan jasmani pada hakikatnya adalah proses pendidikan yang memanfaatkan aktivitas fisik untuk menghasilkan perubahan holistik dalam kualitas individu, baik dalam fisik, mental serta emosional (Mahendra, 2015). Pendidikan jasmani memperlakukan anak sebagai sebuah kesatuan utuh, makhluk total, dari pada hanya menganggapnya sebagai seseorang yang terpisah kualitas fisik dan mentalnya. Pendidikan jasmani juga merupakan salah satu usaha sadar untuk menciptakan lingkungan yang mampu mempengaruhi potensi peserta didik agar berkembang ke arah tingkah laku yang positif melalui aktivitas jasmani (Utama, 2011).

Melihat pengertian pendidikan jasmani dari para ahli diatas pendidikan jasmani memang sudah seharusnya diberikan kepada anak dari usia dini, melalui penjas yang diarahkan dengan baik dan tingkah laku yang positif maka penjas juga dapat membantu mengembangkan kemampuan diantaranya kemampuan fisik, mental dan emosional terdahap aktivitas jasmani. Kemudian dalam ruang lingkup pendidikan jasmani disekolah terutama dalam kurikulum 2013 terdapat salah satu aktivitas pembelajaran yang cocok untuk siswa sekolah dasar aktivitas tersebut adalah aktivitas pola gerak dasar. Pola gerak dasar merupakan pola gerak yang membentuk dasar-dasar dari keterampilan gerak yang kompleks meliputi gerak lokomotor, gerak non lokomotor dan gerak manipulatif.

Keterampilan manipulatif merupakan keterampilan gerak yang penting untuk dikuasai dan dimiliki setiap individu karena gerak manipulatif adalah gerakkan untuk bertindak melakukan suatu bentuk gerak dari anggota badanya secara lebih terampil, keterampilan gerak manipulatif melibatkan tindakan mengontrol suatu objek khususnya dengan tangan dan kaki. Gerak manipulatif adalah gerak yang dikembangkan ketika anak tengah menguasai bermacam objek (Hidayat, 2017). Kemampuan manipulatif lebih banyak melibatkan tangan dan kaki, tetapi bagian lain dari tubuh kita juga dapat digunakan. Gerakan manipulatif adalah gerakan memanipulasi atau memastikan obyek tertentu dengan menggunakan tangan, kaki atau bagian tubuh yang lain (Syahban, 2015). Disebut manipulatif karena pada keterampilan ini, anak- anak harus berhubungan dengan benda diluar dirinya yang harus dimanpulasi sedemikian rupa sehingga terbentuk satu keterampilan.

Penguasaan keterampilan manipulatif dasar memungkinkan anak-anak untuk mencoba gerakan yang lebih terspesialisasi dan kompleks yang merupakan bagian dari permainan dan permainan olahraga yang lebih dinamis dan penguasaan keterampilan tingkat lanjut biasanya diperlukan jika remaja ingin dipertahankan dalam olahraga remaja (McKenzie, 2016). Jadi pada gerakan keterampilan manipulatif anak melakukan dengan gerakkan yang lebih kompleks dan dalam permainan olahraganya masih menggunakan konsep yang dinamis. Keterampilan-keterampilan manipulatif termasuk 
motorik kasar atau motorik halus gerakan, keterampilan manipulatif motorik kasar melibatkan gerakan yang memberi kekuatan pada benda atau menerima kekuatan dari benda (Kalaja, 2012). Melempar, menangkap, menendang, menjebak, menyerang, melakukan tendangan voli, memantul, berguling, dan mengayuh adalah contoh dari keterampilan manipulatif motorik kasar yang mendasar. Keterampilan manipulatif motorik halus mengacu pada aktivitas penanganan objek kecil itu menekankan kontrol motorik, presisi, dan akurasi gerakan.

Proses pembelajaran pendidikan jasmani melalui model pendidikan gerak dapat memberikan banyak pengalaman dan akan menjadi fasilitas baik anak untuk mengembangkan gerakkan lebih kompleks serta koordinasi yang baik. Pandangan utama tentang pendidikan gerak, bersamaan dengan integrasi perkembangan terkini pada bidang ilmu olahraga dan pendidikan gerak di fokuskan pada fakta bahwa sangat penting untuk meningkatkan keaktifan anak-anak dalam berpartisipasi dalam berbagai kegiatan untuk memberikan pengalaman yang efektif dan efisien melalui fungsionalitas metode pendidikan yang digunakan dalam proses belajar mengajar (Altinkök, 2016). Jadi pada pendidikan gerak anak sangat penting untuk difokuskan terhadap peningkatan keaktifan pribadi dalam berpartisipasi atau bersoisialisasi dalam berbagai kegiatan apapun.

Pada dasarnya pelaksanaan model pendidikan gerak adalah penggabungan anatara gerak dasar fundamental dengan konsep gerak. Artinya, pengajaran pendidikan gerak adalah pengajaran gerak dasar fundamental berdasarkan pada penerapan konsep gerak. Gerak dasar fundamental adalah gerakan-gerakan dasar yang berkembangnya terjadi sejalan dengan pertumbuhan tubuh dan tingkat kematangan pada anak -anak (Wibowo, et. Al, 2018). Pentingnya keterampilan gerakan mendasar anak-anak dengan tingkat kompetensi yang tinggi mampu membuat anak berpartisipasi dengan penuh percaya diri dalam berbagai aktivitas (Hands, 2012).

Gerak dasar fundamental didefinisikan sebagai pola belajar gerakan dasar yang tidak terjadi secara alami dan menyarankan untuk menjadi dasar untuk kegiatan fisik dan olahraga yang lebih kompleks (Burstiando \& Kholis, 2017). Gerak dasar fundamental merupakan pola gerakkan yang menjadi dasar untuk ketangkasan gerak yang lebih kompleks Selaras dengan pendapat (Nugraha, et. al, 2018). Disisi lain, keterampilan gerak dasar fundamental dapat dikembangkan melaui aktivitas fisik berupa permainan, karena dengan bermain siswa akan dituntut untuk mengembangkan kreatifitasnya untuk bertindak dan atau mengambil keputusan yang secara interaktif akan membuat siswa berfikir untuk mengeluarkan keterampilan geraknya dalam setiap keputusan yang ia ambil (Fadhillah \& Wibowo, 2018).

Hal yang mirip juga dengan ungkapan diatas gerak dasar atau fundamental motor skills dianggap sebagai blok atau fondasi bangunan untuk keterampilan gerakkan khusus dan olahraga yang diperlukan untuk berpartisipasi dalam berbagai kegiatan fisik (Cohen, et.al 2014). Dapat disimpulkan bawah gerak dasar fundamental adalah pola gerakkan dasar yang menjadi dasar untuk suatu kegiatan aktivitas fisik atau jasmani dalam keterampilan gerak olahraga yang lebih kompleks. Siswa sekolah dasar dapat mengembangkan keterampilan berfikir dan gerakan kreatif setelah 
berpartisipasi dalam program pendidikan gerak (Kulinna, 2008). Struktur permainan sangatlah penting, struktur permainan melibatkan komponen seperti peralatan, jumlah pemain, yang diperlukan untuk memainkan permainan, batasan aturan dan keterampilan yang dibutuhkan untuk menjadi sukses dipermainan (Leech and Marston, 2016).

Pada siswa sekolah dasar kelas 4 terdapat permasalahan yang signifkan terhadap pembelajaran keterampilan lengan, terlihat dari gerakkan melempar, menangkap dan memukul bola nya masih dikatakan sangat rendah, sehingga tujuan penelitian ini adalah untuk meningkatan keterampilan manipulatif lengan melalui model pendidikan gerak berformat permainan.

\section{METODE PENELITIAN}

Dalam penelitian ini peneliti menggunakan desain Penelitian Tindakan Kelas Partisipan dalam penelitian ini peneliti mengambil subjek dari kelas 4C yaitu berjumlah 34 (17 laki-laki dan 17 perempuan). Pemilihan partisipan dilakukan dengan cara keselurahan dalam satu kelas. Intrumen penelitian ini menggunakan lembar observasi dengan format penilaian Game Performance Asessement Instrument dan catatan lapangan.

\section{HASIL PENELITIAN}

Pada Dari hasil penelitian terhadap keterampilan manipulatif lengan pada pembelajaran model pendidikan gerak berformat permainan, terdapat hasil dari Pre-test sebagai berikut :

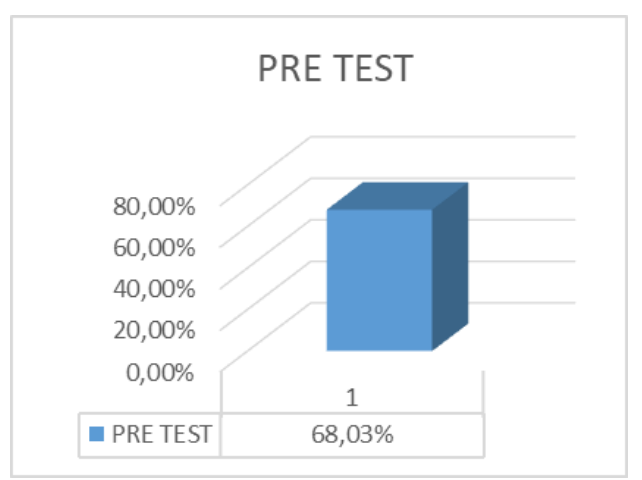

Gambar 1. Hasil Prr-test

Terihat dari tahapan awal ini masih banyak siswa yang melakukan gerakan kurang tepat dari komponen gerakkan manipulatif lengan, pada tahapan ini siswa diberikan komponen gerakkan melempar dan menangkap, dari segi lemparan nya siswa masih banyak yang kurang benar dan dari segi tangkapanya siswa masih banyak yang terlepas. Hasil yang didapatkan pre rata-rata presentase keterampilan siswa sebesar 68,03 \% dari data yang didapat daripre test sangat rendah, Untuk itu penelitian dilanjutkan dengan siklus 1 tindakan 1.

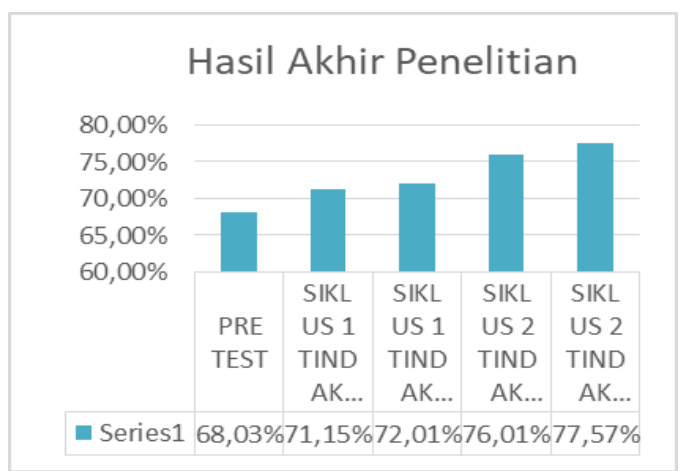

Gambar 2. Hasil Penelitian

Hasil siklus 1 tindakan 1 terlihat dari siswa dalam melakukan keterampilan manipulatif lengan juga terlihat masih rendah, masih banyak yang kurang tepat dalam melakukan 
gerakkan keterampilan manipulatif lengan, pada tahapan ini juga masih diberikan komponen permainan yang nmengarah terhadap gerakkan melempar dan menangkap. masih banyak yang kurang tepat dan terlepas dari segi lemparan dan tangkapanya. Untuk nilai nya juga masi belum mencapai kategori cukup, walaupun mengalami peningkatan $3,12 \%$ yaitu $71,15 \%$. Untuk capaian presentase masih kurang dari mencapai KKM 75\%. Maka dari itu peneliti melanjutkan tindakan selanjutnya yaitu siklus 1 tindakan 2.

Pada siklus 1 tindakan 2 terlihat siswa terlihat masih sama dikatakan rendah, dari melakukan gerakkanya ketika melempar dan menangkap masih tetap kurang efektif dan kurang tepat dan gerakkan melemparnya rata-rata masih banyak yang terlepas. Tetapi peneliti menemukan peningkatan dari hasil pre test, siklus 1 tindakan 1 dan siklus 1 tindakan 2 yaitu $3,98 \%$. Hasil presentase siklus 1 tindakan 2 mencapai $72,01 \%$. Hal ini masih kurang dari presentase nilai KKM yaitu 75\%. Maka dari itu peneliti melanjutkan kembali tindakan selanjutnya yaitu siklus 2 tindakan 1 .

Pada siklus 2 tindakan 1 peneliti memberikan permainan sudah mengarah pada konsep atau komponen gerakkan melempar menangkap dan memukul bola, pada komponenen menangkap dan melempar siswa sudah mulai terlihat hampir tepat dan sudah tidak banyak siswa yang melakukan tangkapanya terlepas, namun pada gerakkan memukul nya masih belum tepat atau efektif, tetapi peneliti menemukan peningkatan dari hasil pre test, siklus 1 tindakan 1 , siklus 1 tindakan 2, dan siklus 2 tindakan 1 yaitu 7,98\%. Hasil presentase siklus 2 tindakan 1 mencapai 76,01\%. Walaupun sudah menagalami capaian nilai KKM yai- tu $75 \%$, tetapi masih cukup kurang, maka dari itu. peneliti masih melanjutkan kembali dengan tindakan selanjutnya yaitu siklus 2 tindakan 2 .

Pada siklus 2 tindakan 2 peneliti melihat untuk gerakkan manipulatif lenganya sudah efektif atau tepat dan juga dari segi komponen melempar, menangkap, dan memukul bola nya sudah benar, pada tahapan ini peneliti menemukan hasil peningkatan yang signifikan dari hasil pre test sampai siklus 2 tindakan 2 , untuk presentase hasil siklus 2 tindakan 2 mencapai $77,57 \%$. Hal ini sudah melampaui presentase nilai KKM yaitu 75\%. Dan untuk gerakkan manipulatif lengan siswa kelas $4 \mathrm{C}$ ini sudah mahir atau bagus. Dalam hal ini peneliti cukupkan untuk melakukan penelitian, dengan demikian dapat disimpulkan bahwa pembelajaran model pendidikan gerak dengan berformat permainan dapat meningkatkan keterampilan manipulatif lengan siswa sekolah dasar kelas 4 .

\section{KESIMPULAN}

Berdasarkan hasil analisis data atau pengolahan analisis data peneliti menyimpulkan melalui pembelajaran model pendidikan gerak berformat permainan memberikan dampak positif terhadap peningkatan keterampilan manipulatif lengan siswa yaitu melempar, menangkap, dan memukul bola.

\section{DAFTAR PUSTAKA}

.Altinkök, M. (2016). The Effects of Coordination and Movement Education on Pre School Children's Basic Motor Skills Improvement. Universal Journal of Educational Research, 4(5), 1050-1058. https://doi.org/10.13189/ ujer.2016.040515

Burstiando \& Kholis. (2017). Jurnal Pembelajaran Olahraga http:/ ojs.unpkediri.ac.id/index.php/pjk/index 
Volume 3 Nomor 1 Tahun 2017. Jurnal Pembelajaran Olahraga, 3(2), 167-177. https://doi.org/10.1097/00001888199401000-00014

Cohen, K. E., Morgan,P. J., Plotnikoff, R. C., Callister, R., \& Lubans, D. R. (2014). Fundamental movement skills and physical activity among children living in low-income communities: A crosssectional study. International Journal of Behavioral Nutrition and Physical Activity, 11(1), 1-9. https:// doi.org/10.1186/1479-5868-11-49

Fadilah, M., \& Wibowo, R. (2018). Kontribusi Keterampilan Gerak Fundamental Terhadap Keterampilan Bermain SmallSided Handball Games. Jurnal Pendidikan Jasmani Dan Olahraga, 3(1), 60. https://doi.org/10.17509/jpjo.v3i1.7667

Hands, B. (2012). How fundamental are fundamental movement skills? Australian Council for Health, Physical Education \& Recreation Inc., 19(1), 14-17

Hidayat, A. (2017). Peningkatan aktivitas gerak lokomotor, nonlokomotor dan manipulatif menggunakan model permainan pada siswa sekolah dasar. Jurnal Pendidikan Jasmani Dan Olahraga, 9 (September), 21-29.

Kalaja, S. P., Jaakkola, T. T., Liukkonen, J. O., \& Digelidis, N. (2012). Development of junior high school students' fundamental movement skills and physical activity in a naturalistic physical education setting. Physical Education and Sport Pedagogy, 17(4), 411-428. https://

doi.org/10.1080/17408989.2011.60312 4

Kulinna, P. H. (2008). Models for Curriculum and Physical Education. The Elementary School Journal, 108(3), 219-227.

Leech, T., \& Marston, R. (2016). Promoting Physical Activity beyond Physical Education by Facilitating Student-designed Games. Journal of Physical Education, Recreation \& Dance, 87(9), 8-13. https://

doi.org/10.1080/07303084.2016.12262 18

Mahendra, A. (2015). Filsafat Pendidikan Jasmani: Dasar-Dasar Pembelajaran Pen- jas di Sekolah Dasar. Bandung: CV. Bintang Warliartika

McKenzie, T. L., Alcaraz, J. E., Sallis, J. F., \& Faucette, F. N. (2016). Effects of a Physical Education Program on Children's Manipulative Skills. Journal of Teaching in Physical Education, 17(3), 327-341. jtpe.17.3.327

Nugraha, L., Mahendra, A., \& Herdiyana, I. (2018). Penerapan Model Pendidikan Gerak Dalam Pengembangan Pola Gerak Dasar Manipulatif Melalui Kerangka Analisis gerak ( Movement Analysis Framework ), TEGAR. Journal of Teaching Physical Education in Elementary School 1(2), 24-32

Syahban, A (2015). Gerak Dasar. [Online].Diakses:https:// arham892.blogspot.com/2015/12/gerak -dasar.html

Utama, A. M. B., Yogyakarta, U. N., No, J. K., \& Yogyakarta, K. (2011). Abdullah: Dasar-Dasar Pendidikan Jasmani Google Scholar, 8(April), 1-9. Retrieved fromhttps://scholar.google.com/ scholar? cites $=4695785154429841909 \&$ as_sdt $=$ $2005 \&$ sciodt $=0,5 \& \mathrm{hl}=\mathrm{e}$

Wibowo, R., Nugraha, E., \& Sultoni, K. (2018). Fundamental Movement Skills and Moods as Predictors of Games Performance in Primary School Students. ACTIVE: Journal of Physical Education, Sport, Health and Recreation, 7 (1), 44-49. 